\title{
Kömür Baca Külü, Kireç ve Jips Ürünlerinden Yapı Malzemesi Yapımı
}

\author{
${ }^{1}$ Salih Yüksek*, ${ }^{1}$ Semih Kaya \\ ${ }^{1}$ Cumhuriyet Üniversitesi Mühendislik Fakültesi Maden Mühendisliği Bölümü, 58140 Sivas
}

\begin{abstract}
$\ddot{O} z$
Termik santrallerde linyit kömürünün yakılması sonucu ortaya çıkan toplam katı atığın ortalama \% 80 'i baca külü ve $\% 20$ 'si taban külü olup doğal arazilerde depolanmaktadır. Santrallerde $1 \mathrm{kWh}$ 'lik enerji üretmek için yaklaşık 110 gram kül atık olarak ortaya çıkmakta ve 1000 MW'lık bir santralden yılda 650 bin ton kül atığı oluşmaktadır. Ülkemizde faal olarak çalışan termik santrallerden yılda yaklaşık 20 bin MW elektrik enerjisi üretilirken 13 milyon ton kül ortaya çıkmaktadır. Kurulu gücü $457 \mathrm{MW}$ olan Sivas-Kangal termik santralinden yılda yaklaşık 400 bin ton kül açığa çıkmakta olup bu atıklar hâlihazırda herhangi bir biçimde değerlendirilmemektedir. Sivas havzasında milyarlarca tonluk jips kaynakları bulunmaktadır. Bu çalışmada Kangal Termik santrali uçucu külü ile alçı ve kirecin değişik oranlarda karışımları ile hafif yapı malzemesi üretimi deneysel olarak araştırılmışstır. Elde edilen numuneler üzerinde standartlarda istenilen deneyler gerçekleştirilmiştir. D-17 etiketli kütlece $\% 70$ alçı, \% 10 uçucu kül ve \% 20 oranlarındaki karışım diğer karışımlara göre daha optimal değerlere sahip olduğu belirlenmiştir. D-17 etiketli numune dizilerine değişik katkılar ilavesiyle basınç mukavemeti $92,8 \mathrm{~kg} / \mathrm{cm}^{2}$ 'den $113,8 \mathrm{~kg} / \mathrm{cm}^{2}$ ye yükseltilirken su emme oranları $\% 45,8$ 'den $\% 19,1$ 'e ve su uzaklaştırıcı madde ilavesiyle $\% 6,9$ 'a indirilmiştir. Tüm numunelerin yoğunluk ile eğilme mukavemeti arasında yüksek korelosyonlu $\left(\mathrm{R}^{2}=0,95\right)$ doğrusal ilişki olduğu, Shore sertlik değeri ile eğilme mukavemeti arasında üssel bir ilişki $\left(R^{2}=0,81\right)$ olduğu görülmüştür.
\end{abstract}

Anahtar Kelimeler: Baca külü, Jips, Kireç

\section{Building Material Production from Fly Ash, Lime and Gypsum}

\begin{abstract}
Approximately 80 per cent and 20 per cent of the total solid waste resulting from the burning of lignite coal in thermal power plants are fly ash and bottom ash, respectively. This material is stored in natural terrain. In order to generate 1 $\mathrm{kWh}$ of power approximately 110 grams of ash is produced and a thermal power plant of $1000 \mathrm{MW}$ capacity produces some 650000 tons of ash on a yearly basis. About 20,000 MW of electricity is generated annually from thermal power plants operating in our country, resulting in 13 million tons of ash. Some 400 thousand tons of ash per year is being produced in Sivas-Kangal thermal power plant of 457 MW installed capacity. This material is not considered in any way. Sivas basin contains billions of tons of gypsum resources. In this study, production of lightweight building material was investigated experimentally by mixing different ratios of gypsum and lime with the Kangal thermal power plant fly ash. Required tests were carried out in accordance with relevant standards. It has been determined that D-17 labeled mass $70 \%$ plaster, $10 \%$ fly ash and $20 \%$ of the mixture have more optimal values than the other mixtures. With the addition of different additives to the sample series labeled D-17, the pressure resistance increased from $92,8 \mathrm{~kg} /$ $\mathrm{cm}^{2}$ to $113,8 \mathrm{~kg} / \mathrm{cm}^{2}$, while the water absorption ratios were reduced from $45,8 \%$ to $19,1 \%$ and to $6,9 \%$ with the addition of water repellent. It was found that there is an exponential relationship between Shore hardness value and bending strength $\left(R^{2}=0,81\right)$ that all samples have a high correlation $\left(R^{2}=0.95\right)$ linear relationship between density and bending strength.
\end{abstract}

Keywords: Fly ash, Gypsum, Lime

\section{Giriş}

Termik santrallerin kapasitelerindeki hızlı artış gereği her yıl milyonlarca ton uçucu kül atık malzemesi olarak ortaya çıkmaktadır. Uçucu kül miktarının artması gerek çevresel problemler gerekse ekolojik dengenin bozulmasına neden olmaktadır. Bugün Dünya'da ortaya çıkan uçucu kül miktarı yılda 600

Sorumlu Yazar: Cumhuriyet Üniversitesi Mühendislik Fakültesi Maden Mühendisliği Bölümü, 58140, Sivas, E mail: syuksek@cumhuriyet.edu.tr, Tel: 03462191010 
milyon ton civarındadır. Türkiye'de halen AfşinElbistan, Çatalağzı, Çayırhan, Kangal, Kemerköy, Orhaneli, Seyitömer, Soma, Tunçbilek, Yatağan ve Yeniköy santralları aktif olarak faaliyet göstermektedir. Bu santrallerden yıllık uçucu kül atığ ortalama 13 milyon ton kadar olmakta, ancak doğalgaz santrallarının devreye girmesi ile yıldan yila değişmektedir [1]. Türkiye'deki termik santrallerde kullanılan kömürler ve açığa çıkan kül miktarları Şekil 1 'de özetlenmiştir[2]. Avrupa topluluğu ülkelerinde oluşan külün veya uçucu külün \%15'i, Amerika Birleşik Devletlerinde ise \%20-30’u değişik sektörlerde hammadde olarak kullanılırken ülkemizde bu oran \%1'i geçememektedir. Termik santral küllerinin kullanımının başında çimento ve betonda katkı maddesi, yol yapımında dolgu maddesi, zemin stabilizasyonu ve beton blok olarak kullanılması gelir. Son yıllarda birçok araştırmacı tarafından termik santral atığı küllerden tuğla olabilirliği üzerine araştırmalar yapılmaktadır [3, 4, 5, 6, 7, 8, 9]. Çalışmaların çoğunda geleneksel kille baca külünün belli oranlarda karıştırılması ve pişirilmesi ile tuğla yapımı araştırılmıştır. Bu çalışmada ise, sade alçı, kireç, termik santral uçucu külü ve suyun farklı oranlarda karıştırılmasıyla doğal ortamda kurutularak mukavemet kazandırılmıştır.

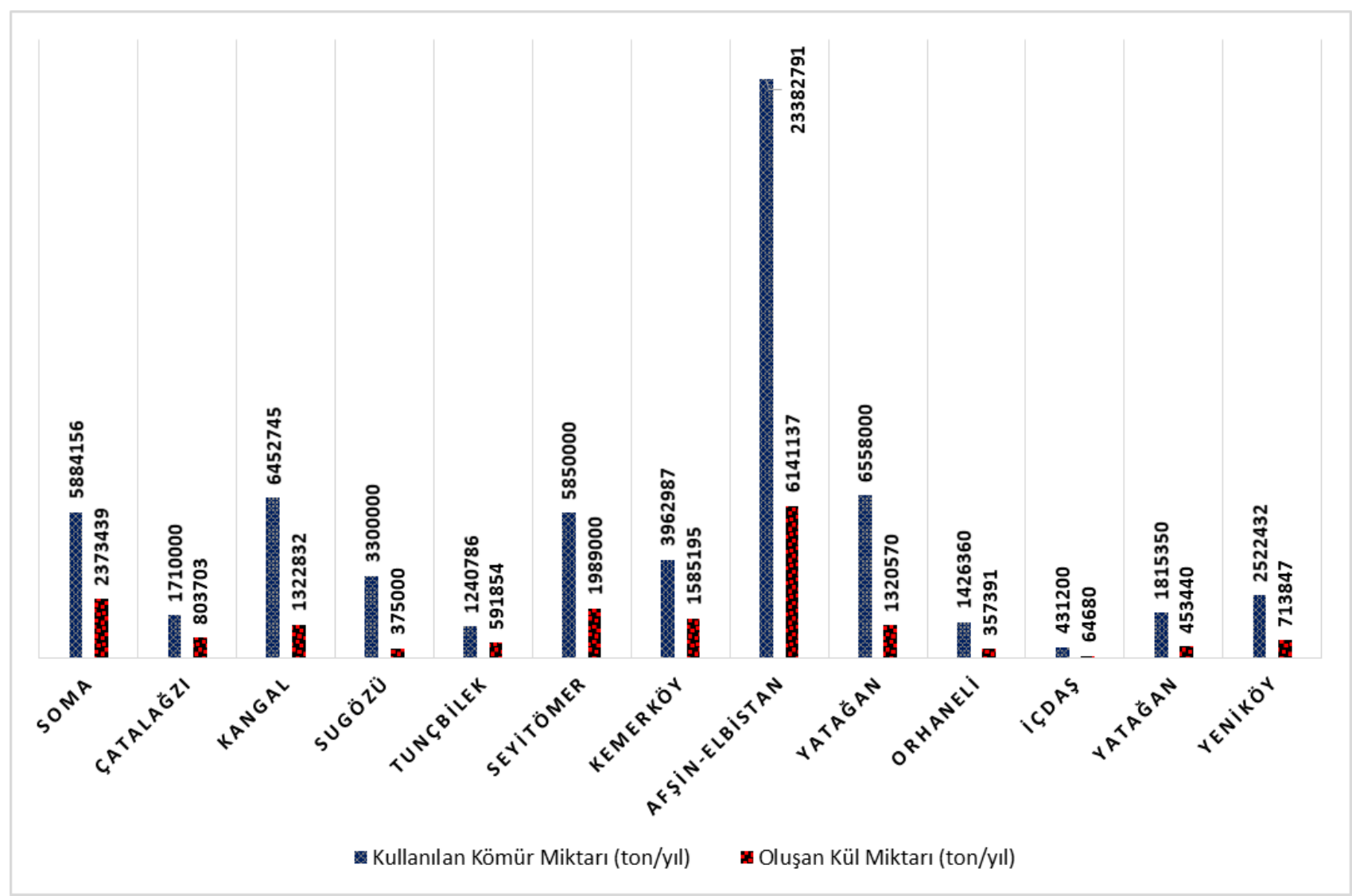

Şekil 1. Termik santrallerde yıllık kullanılan kömür tonajı ve oluşan kül miktarları [2]' den düzenlenmiştir.

\section{Materyal ve Metot}

$\mathrm{Bu}$ çalışmada tuğla örneklerinin hazırlanmasında kullanılan uçucu kül Kangal Termik santralinden, alçı Sivas Akkaya bölgesinde jips ürünleri üreten bir fabrikadan ve kireç malzemesi ise Sivas merkeze yakın Tecer kireçtaşlarından üretim yapan bir fabrikadan temin edilmiştir. Tuğla numunelerinin hazırlanmasında kullanılan malzemeler olan sade alçı, uçucu kül ve kirecin kimyasal analiz (XRF) sonuçları
Tablo 1, Tablo 2 ve Tablo 3'de verilmiştir. Uçucu kül ve sade alçının kimyasal analizleri Cumhuriyet Üniversitesi Mühendislik Fakültesinde yapılmış, kirecin kimyasal analizi ise Kireç Firmasının yaptırdığg analiz değerleridir. Kangal uçucu külü, TS EN 197-1'e göre, reaktif kireci \% 10'un üzerinde olduğu için kalkersi uçucu kül (W) sınıfına girmektedir. ASTM C 618'e göre $\mathrm{SiO}_{2}+\mathrm{Al}_{2} \mathrm{O}_{3}+\mathrm{Fe}_{2} \mathrm{O}_{3}$ miktarı yani $\mathrm{S}+\mathrm{A}+\mathrm{F}>$ \%50 olduğu için bu kül C sınıfı (yüksek kireçli) uçucu kül kapsamına girmektedir. Kangal uçucu külü, yüksek 
kireçli uçucu kül $(\mathrm{CaO}>\% 10)$ olduğu için serbest kireç miktarı ortalamada \% 7.65 olup, TS EN 450’ de verilen \%1.0 sınırının üzerindedir[10, 11].

Tablo 1. Sade alçının kimyasal bileşimi (XRF sonuçlari)

\begin{tabular}{ccccc}
\hline \multicolumn{5}{c}{ \% Bileşen } \\
$\mathrm{H}_{2} \mathrm{O}$ & $\mathrm{CaO}$ & $\mathrm{SO}_{3}$ & $\mathrm{SiO}_{2}$ & $\mathrm{NaCl}$ \\
\hline 4.50 & 37.45 & 53.50 & 0.25 & 0.01 \\
\hline
\end{tabular}

Tablo 2. Uçucu külün kimyasal bileşimi (XRF

\begin{tabular}{ccccc}
\multicolumn{5}{c}{ sonuçları) } \\
\hline \multicolumn{5}{c}{ \% Bileşen } \\
$\mathrm{Al}_{2} \mathrm{O}_{3}$ & $\mathrm{Fe}_{2} \mathrm{O}_{3}$ & $\mathrm{CaO}$ & $\mathrm{MgO}$ & $\mathrm{SiO}_{2}$ \\
\hline 12.07 & 4.51 & 24.38 & 2.69 & 40.70 \\
\hline
\end{tabular}

Tablo 3. Kirecin kimyasal bileşimi

\begin{tabular}{|c|c|c|c|c|}
\hline \multirow[b]{2}{*}{$\mathrm{CaO}$} & \multicolumn{4}{|c|}{ \% Bileşen } \\
\hline & $\mathrm{MgO}$ & $\begin{array}{c}\text { Kizdirma } \\
\text { kayb1 }\end{array}$ & $\begin{array}{c}\text { Son } \\
\text { Sicaklık }\end{array}$ & $\begin{array}{c}\text { T } 60 \\
\text { Değeri }\end{array}$ \\
\hline 90.19 & 1.12 & 3.98 & 71.6 & 28.50 \\
\hline
\end{tabular}

Ticari adları Melment ve Sica olan katkılar kullanarak uçucu kül katkılı tuğla yapmak amacıyla $160 \mathrm{~mm} \times 40$ $\mathrm{mm} \times 40 \mathrm{~mm}$ boyutlarında kalıp hazırlanmıştır. Sade alçı, termik santral uçucu külü ve kirecin, boyut analizleri, kimyasal analizleri, özgül ağırlıkları ve termik santral uçucu külünün nem kaybı belirlenmiştir. Hazırlanan karışımların (Sade alçı + Uçucu kül + Kireç $+\mathrm{Su}$ ) ise kalıplara dökülmeden önce harç kıvamlarının bütün örneklerde aynı olması için çap analizleri yapılmıştır. Ayrıca örnek numunelerin ilk katılaşma ve son katılaşma süreleri belirlenmiştir. Daha sonra her birinden beşer adet olmak üzere 17 farklı şekilde sade alçı, uçucu kül, kireç ve su karışımları oluşturulmuştur. Oluşturulan bu numunelerin karışım kodları-yüzdesel oranları, katılaşma süreleri ve yoğunlukları Tablo 4'de toplu olarak verilmiştir.

Kalıplardan çıkarılan tuğla numunelerinin kurutulması için laboratuvarda $15,30,45$ ve 60 gün süre ile bekletilmiştir (Şekil 2). Laboratuvarda bekletilen tuğla numuneleri üzerine kalıptan çıkarıldıkları günden itibaren 15 'er gün aralıklarla, basınç dayanımı, su emme, eğilme mukavemeti, yüzey sertliği ve özgül ağırlık deneyleri uygulanmıştır. Deneylere 60. gün sonuna kadar devam edilmiştir. Numunelerin bekletilme süreleri deneylerde iyileştirme yöntemi olarak belirlenmiştir.

Tablo 4. Tuğla numunelerinin hazırlanmasında elde edilen veriler

\begin{tabular}{|c|c|c|c|c|c|}
\hline Kod & $\begin{array}{l}\text { Karışım } \\
\text { oranları }\end{array}$ & $\begin{array}{l}\text { Su/karışım } \\
\text { oranları }(\%)\end{array}$ & $\begin{array}{l}\text { İlk katılaşma } \\
\text { (ti) } \\
\text { (dk:sn) }\end{array}$ & $\begin{array}{c}\text { Son katılaşma } \\
(\mathrm{td}) \\
(\mathrm{dk}: \mathrm{sn})\end{array}$ & $\begin{array}{l}\text { Yoğunluk (d) } \\
\left(\mathrm{g} / \mathrm{cm}^{3}\right)\end{array}$ \\
\hline D-1 & $\% 100 A^{*}$ & 69 & $11: 50$ & $28: 00$ & 1.59 \\
\hline D-2 & $\% 80 \mathrm{~A}+\% 20 \mathrm{UK}^{* *}$ & 74 & 07:40 & 19:00 & 1.52 \\
\hline D-3 & $\% 60 \mathrm{~A}+\% 40 \mathrm{UK}$ & 80 & $06: 20$ & 16:00 & 1.45 \\
\hline D-4 & $\% 40 \mathrm{~A}+\% 60 \mathrm{UK}$ & 84 & $05: 50$ & 14:00 & 1.41 \\
\hline D-5 & $\% 20 \mathrm{~A}+\% 80 \mathrm{UK}$ & 86 & $14: 50$ & & \\
\hline D-6 & $\% 40 \mathrm{~A}+\% 45 \mathrm{UK}+\% 15 \mathrm{~K}^{* * *}$ & 75 & 09:00 & 22:00 & 1.40 \\
\hline D-7 & $\% 40 \mathrm{~A}+\% 30 \mathrm{UK}+\% 30 \mathrm{~K}$ & 80 & $10: 10$ & 24:00 & 1.36 \\
\hline D-8 & $\% 40 \mathrm{~A}+\% 15 \mathrm{UK}+\% 45 \mathrm{~K}$ & 95 & $12: 00$ & $25: 20$ & 1.34 \\
\hline D-9 & $\% 50 \mathrm{~A}+\% 40 \mathrm{UK}+\% 10 \mathrm{~K}$ & 65 & 07:30 & 18:50 & 1.47 \\
\hline D-10 & $\% 50 \mathrm{~A}+\% 25 \mathrm{UK}+\% 25 \mathrm{~K}$ & 75 & 08:40 & 21:00 & 1.46 \\
\hline D-11 & $\% 50 \mathrm{~A}+\% 10 \mathrm{UK}+\% 40 \mathrm{~K}$ & 85 & $10: 00$ & 23:30 & 1.45 \\
\hline D-12 & $\% 60 \mathrm{~A}+\% 30 \mathrm{UK}+\% 10 \mathrm{~K}$ & 80 & 06:00 & $15: 45$ & 1.46 \\
\hline D-13 & $\% 60 \mathrm{~A}+\% 20 \mathrm{UK}+\% 20 \mathrm{~K}$ & 82 & 08:00 & 20:00 & 1.45 \\
\hline D-14 & $\% 60 \mathrm{~A}+\% 10 \mathrm{UK}+\% 30 \mathrm{~K}$ & 84 & $12: 00$ & $25: 10$ & 1.44 \\
\hline D-15 & $\% 70 \mathrm{~A}+\% 20 \mathrm{UK}+\% 10 \mathrm{~K}$ & 72 & $05: 20$ & $14: 00$ & 1.49 \\
\hline D-16 & $\% 70 \mathrm{~A}+\% 15 \mathrm{UK}+\% 15 \mathrm{~K}$ & 74 & $06: 30$ & 15:00 & 1.48 \\
\hline D-17 & $\% 70 \mathrm{~A}+\% 10 \mathrm{UK}+\% 20 \mathrm{~K}$ & 76 & $06: 50$ & $15: 20$ & 1.47 \\
\hline
\end{tabular}

$\mathrm{A}^{*}$ : Sade Alçı UK ${ }^{* *}$ : Uçucu Kül K***: Kireç 


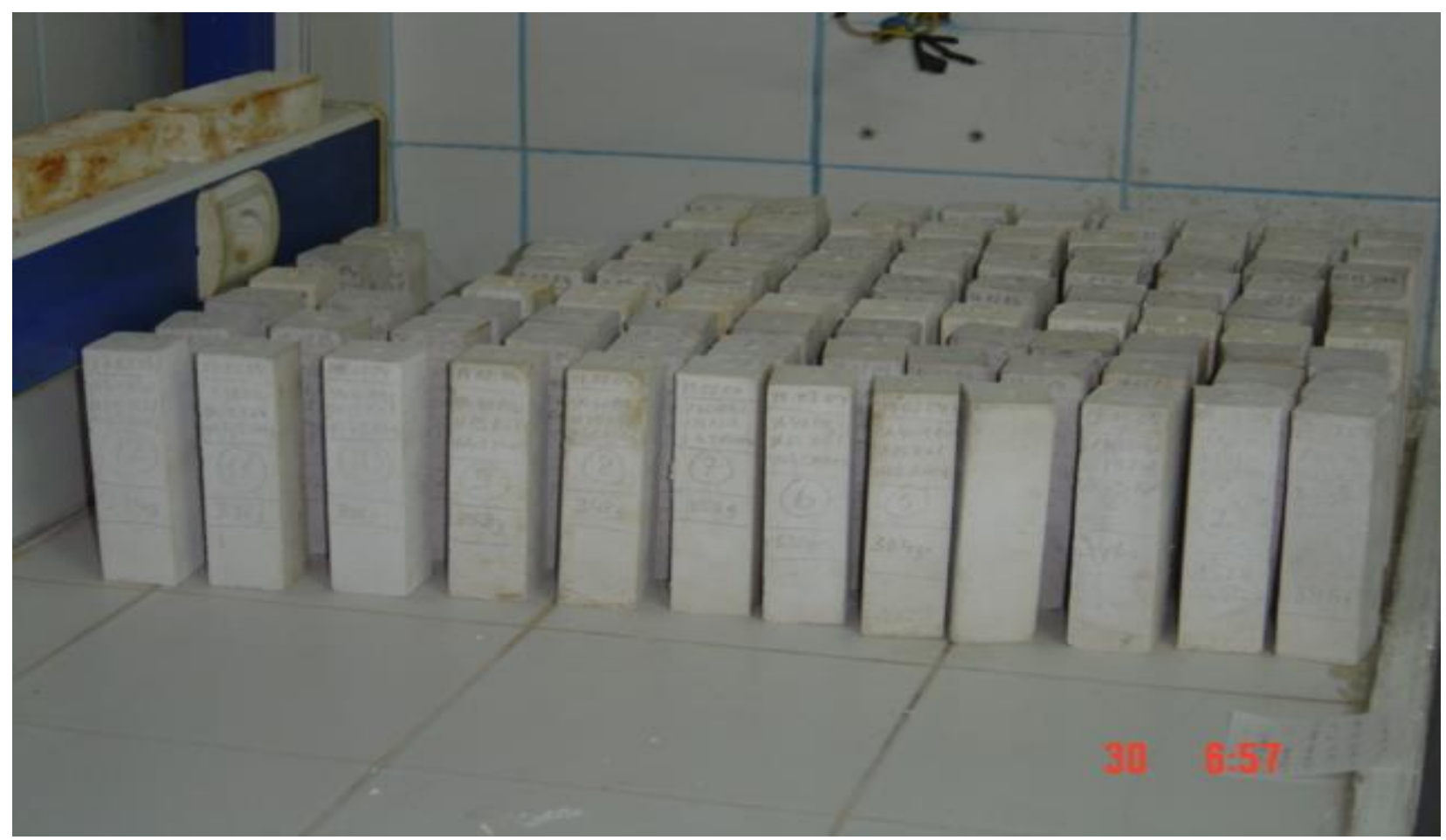

Şekil 2. Kalıptan çıkarılmış tuğla numuneleri

\section{Bulgular ve Tartışma}

Deneyler sonucunda her bir tuğla numunesi için hesaplanan ortalama basınç dayanımı ve porozite değerleri Tablo 5'de özetlenmiştir. Tablo 5'de görüldüğü gibi tuğla numunelerin kalıplarından çıkarılmasından sonra 15. gün sonunda yapılan deneylerde en yüksek basınç dayanımına ve en düşük poroziteye sahip tuğla numunesi D-1 olarak isimlendirilen \%100 Sade alçıdan üretilmiş tuğladır. Ancak bu tuğlanın basınç dayanımının zamanla herhangi bir değiş̧iklik göstermediği gözlenmiştir. Bunun yanında Tablo 4'de karışım oranları verilen D16 ve $\mathrm{D}-17$ tuğlalarının bekleme süreleri sonunda $\mathrm{D}-1$ tuğlasının basınç dayanımı değerine yaklaştığı ve D-17 tuğlasının basınç dayanımı değerinin D-1 tuğlasının basınç dayanımı değerini geçtiği görülmektedir. Tuğla numunelerinin D-1 hariç diğerlerinde bekleme süreleriyle birlikte basınç dayanımlarında artış gözlenmiştir. Bu mukavemet artışları 45.gün sonunda yapılan deneylere kadar devam etmiş daha sonra ise tuğla numunelerinin 45. gün sonundaki mevcut mukavemetlerinin korunduğu ve çok küçük değerler dışında bir değişim olmadığı gözlenmiştir. Sade alçı ve kirecin bağlayıcı özelliğinin yükssek olmasıyla birlikte, bu karışımlar içerisindeki uçucu külün, tuğlaların dayanımını zamanla arttırması özelliği göstermesiyle uçucu kül katkısın önemi görülmüştür. Bekletilme süreleriyle birlikte tuğla numunelerinin üzerinde yapılan basınç dayanımı deneylerinde uçucu kül ve kireç katkısının önemi görülmektedir.

Diğer yandan D-5 (\%20 sade alçı $+\% 80$ uçucu kül) tuğlasının kalıplarda uzun süre bekletildiği halde tuğla numunesi oluşturacak dayanıma ulaşamadıkları gözlenmiştir. Tuğlaların basınç dayanımı deneyi sonuçlarının daha iyi görülmesi ve karşılaştırılabilmesi bakımından aynı sade alçı oranlarıyla yapılmış tuğla numunelerinin basınç dayanımı ile bekleme süreleri arasındaki ilişkiler aşağıdaki şekillerde verilmiştir (Şekil 3, Şekil 4, Şekil 5, Şekil 6). 
Tablo 5. Bekletilen tuğla numunelerinin basınç dayanımı ve porozite sonuçları

\begin{tabular}{lrrrrrrrr}
\hline Kod & \multicolumn{3}{c}{ Basinç Dayanımi $\left(\mathrm{kg} / \mathrm{cm}^{2}\right)$} \\
& \multicolumn{3}{c}{ Numunelerin bekletilme süreleri (gün) } & \multicolumn{5}{c}{ Porozite $(\%)$} \\
\multicolumn{1}{r}{} & 15 Gün & 30 Gün & 45 Gün & 60 Gün & 15 Gün & 30 Gün & 45 Gün & 60 Gün \\
\hline D-1 & 91.6 & 91.6 & 91.6 & 91.6 & 27.0 & 27.2 & 27.1 & 27.0 \\
D-2 & 75.6 & 84.6 & 87.8 & 87.9 & 41.7 & 42.2 & 42.4 & 42.3 \\
D-3 & 31.5 & 3.6 & 38.9 & 38.7 & 53.6 & 53.7 & 52.3 & 52.4 \\
D-4 & 13.4 & 18.6 & 23.4 & 23.4 & 64.5 & 65.2 & 63.4 & 63.6 \\
D-5 & - & - & - & - & - & - & - & - \\
D-6 & 20.8 & 25.2 & 29.8 & 29.9 & 55.6 & 55.0 & 53.4 & 53.6 \\
D-7 & 22.4 & 26.0 & 33.4 & 33.3 & 59.6 & 58.8 & 56.2 & 56.0 \\
D-8 & 22.7 & 29.6 & 36.9 & 36.9 & 70.1 & 65.7 & 66.5 & 66.5 \\
D-9 & 38.5 & 41.3 & 43.4 & 43.5 & 43.9 & 46.5 & 43.0 & 44.0 \\
D-10 & 39.2 & 42.6 & 44.9 & 44.8 & 50.6 & 50.9 & 48.3 & 49.2 \\
D-11 & 41.1 & 44.6 & 46.9 & 46.8 & 57.5 & 59.1 & 53.7 & 55.5 \\
D-12 & 45.7 & 48.3 & 51.0 & 50.9 & 52.8 & 52.0 & 52.0 & 52.0 \\
D-13 & 48.1 & 51.6 & 54.5 & 54.4 & 54.0 & 52.7 & 52.6 & 52.3 \\
D-14 & 51.1 & 54.1 & 57.8 & 57.6 & 56.0 & 56.4 & 56.2 & 56.0 \\
D-15 & 83.0 & 86.7 & 89.5 & 89.5 & 44.2 & 44.2 & 45.2 & 43.2 \\
D-16 & 83.7 & 87.7 & 91.4 & 91.0 & 44.9 & 45.1 & 45.5 & 43.6 \\
D-17 & 84.0 & 88.5 & 92.7 & 92.8 & 45.9 & 45.3 & 45.8 & 45.8 \\
\hline
\end{tabular}

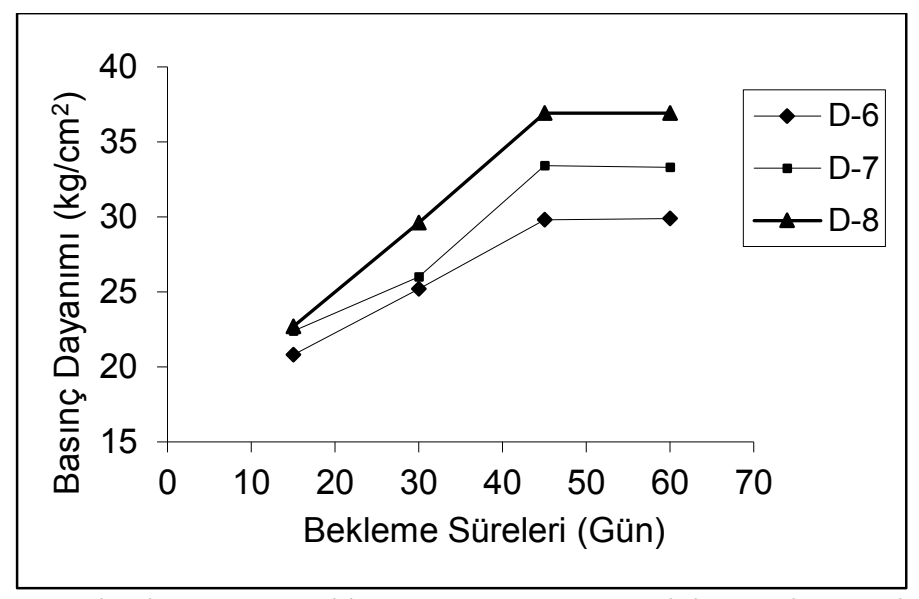

Şekil 3. \%40 sade alçı oranına sahip D-6, D-7 ve D-8 tuğlalarının basınç dayanımları

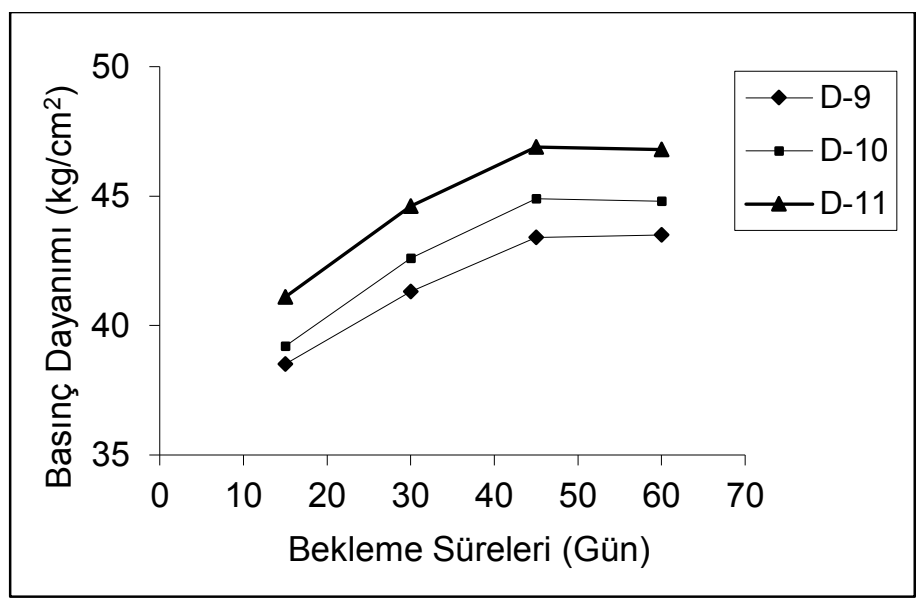

Şekil 4. \%50 sade alçı oranına sahip D-9, D-10 ve D-11 tuğlalarının basınç dayanımları 


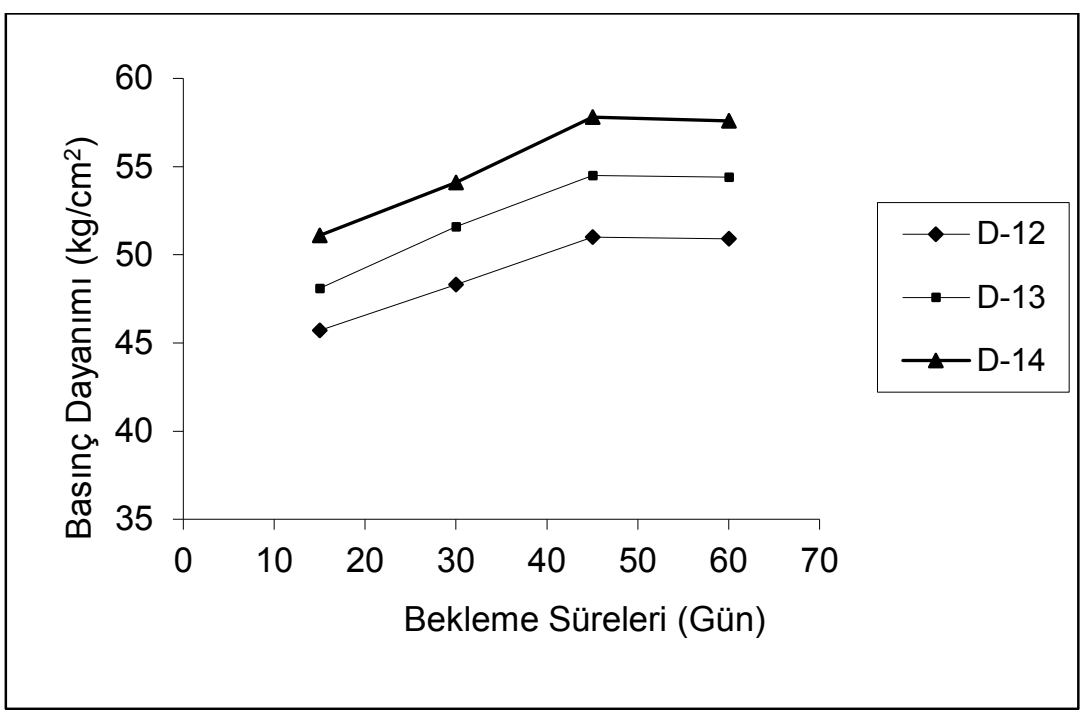

Şekil 5. \%60 sade alçı oranına sahip D-12, D-13 ve D-14 tuğlalarının basınç dayanımları

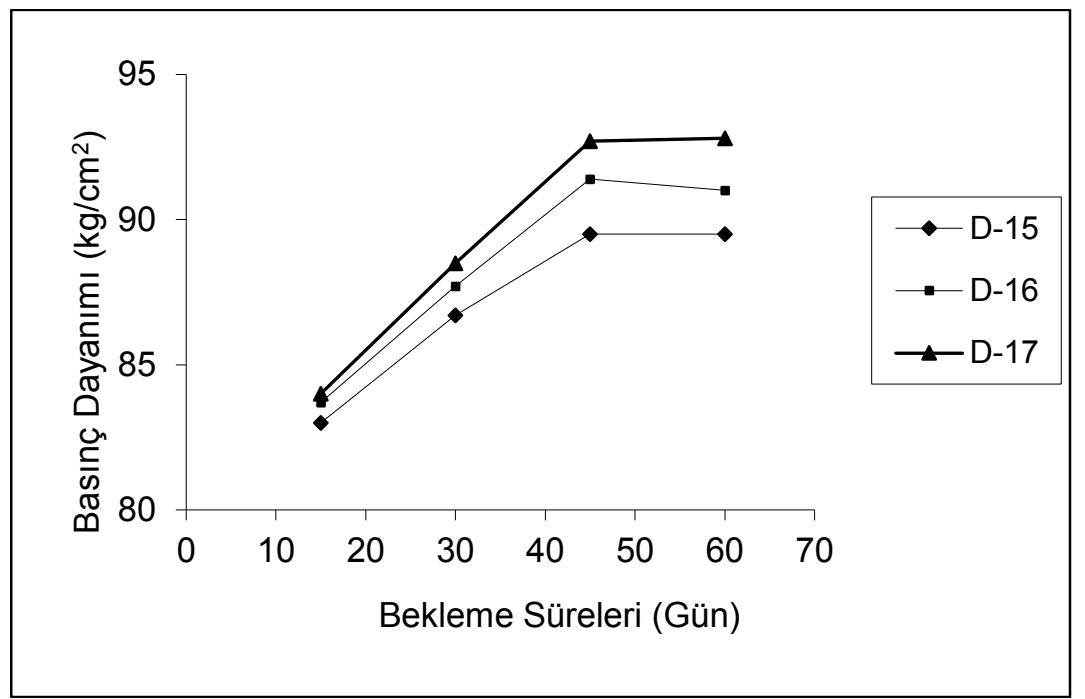

Şekil 6. \%70 sade alçı oranına sahip D-15, D-16 ve D-17 tuğlalarının basınç dayanımları

Benzer biçimde tuğla numunelerinin porozite deneyi sonuçlarının daha iyi görülmesi ve karşılaştırılabilmesi bakımından aynı sade alçı oranlarıyla yapılmış tuğla numunelerinin poroziteleri ile bekleme süreleri arasındaki ilişkiler aşağıdaki şekillerde verilmiş̧ir (Şekil 7, Şekil 8, Şekil 9, Şekil 10). 


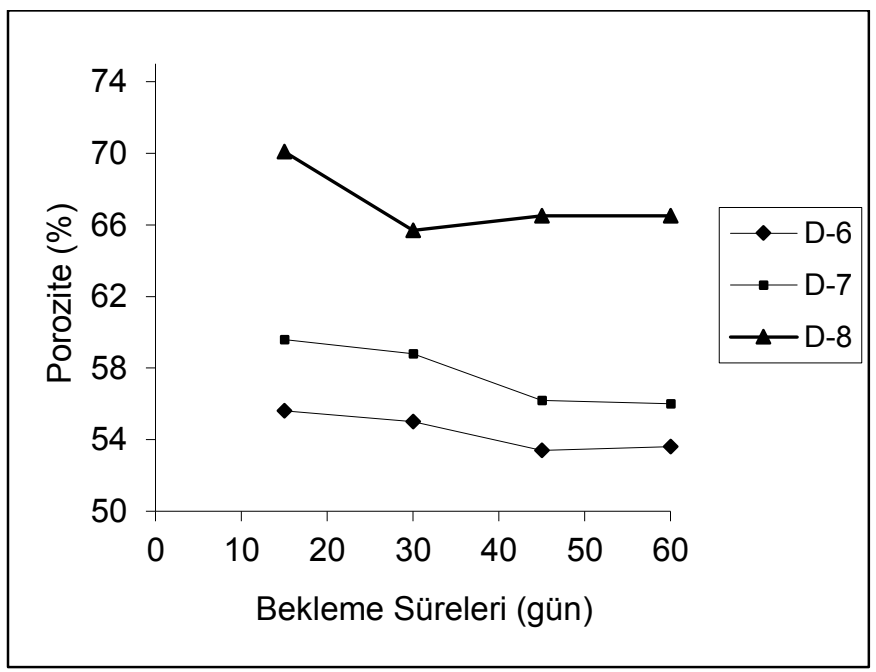

Şekil 7. \%40 sade alçı oranına sahip D-6, D-7 ve D-8 tuğlalarının porozitesi

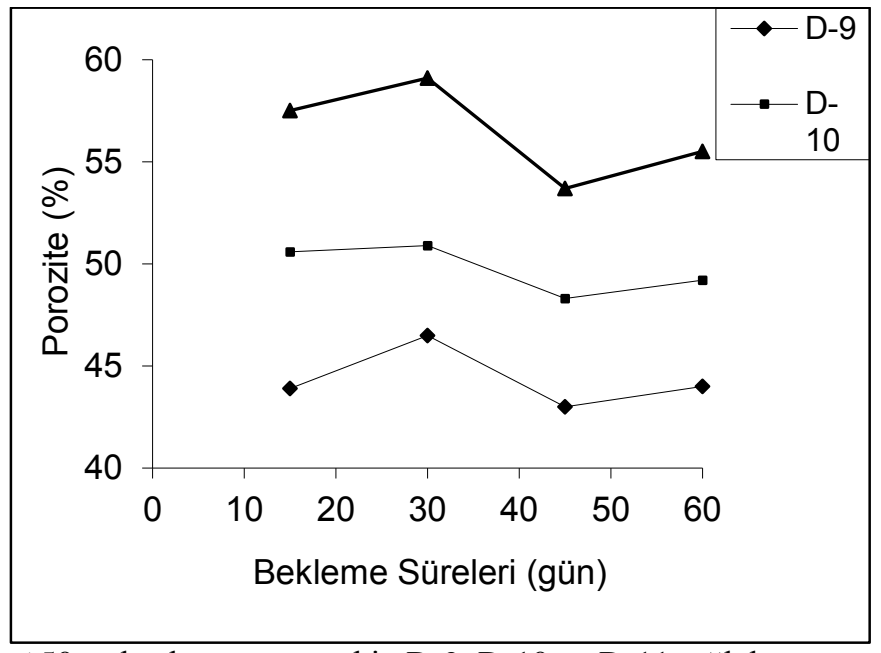

Şekil 8. \%50 sade alçı oranına sahip D-9, D-10 ve D-11 tuğlalarının porozitesi

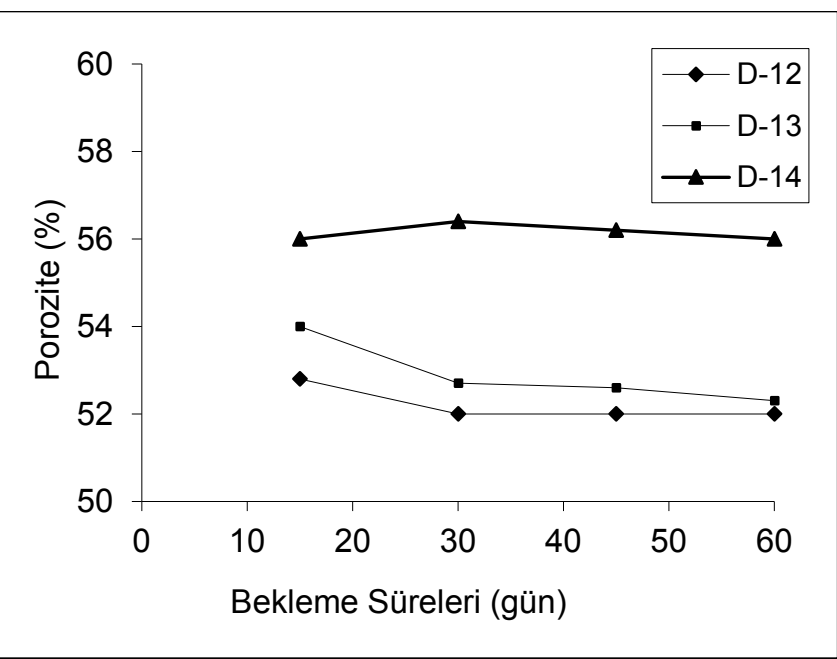

Şekil 9. \%60 sade alçı oranına sahip D-12, D-13 ve D-14 tuğlalarının porozitesi 


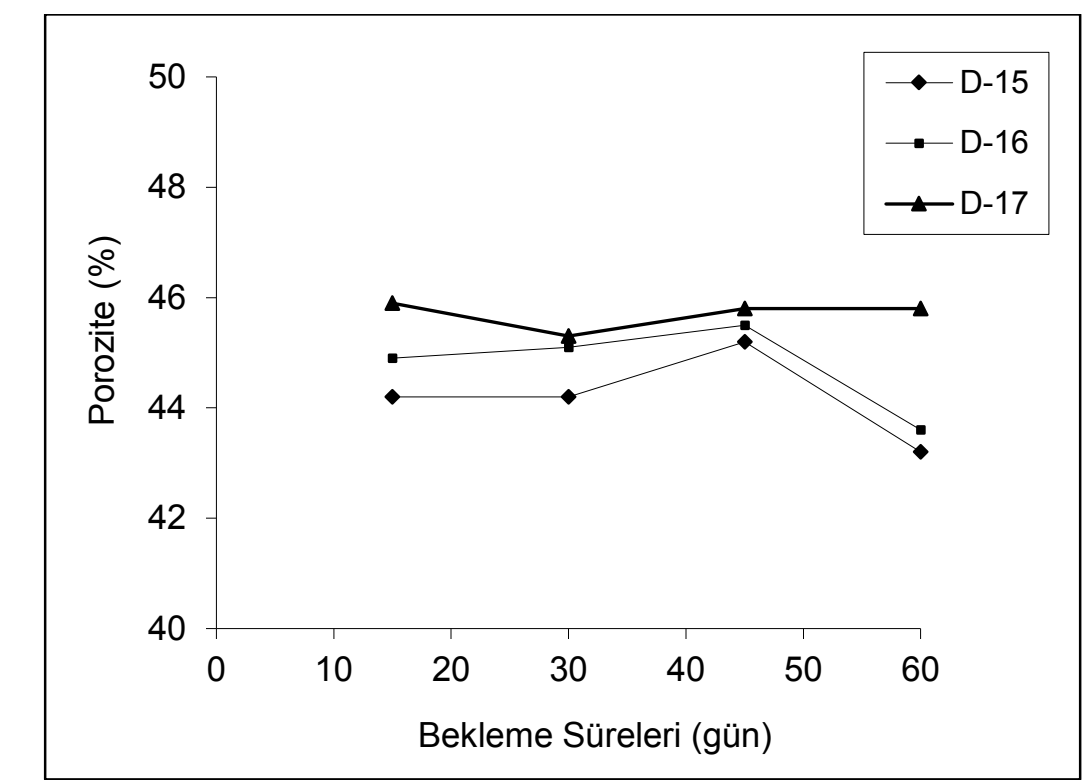

Şekil 10. \%70 sade alçı oranına sahip D-15, D-16 ve D-17 tuğlalarının porozitesi

Grafiklerden de görüldüğ̈̈ gibi bekleme süreleri tuğlaların basınç dayanımlarını \% 8 ila 12.5 oranında arttırmış, porozite değerlerinde ise 15 gün sonunda yapilan deneylerle 45 . gün sonunda yapılan deneylerin sonuçları karşılaştırıldığında \%1 ila \%4 arasında değişen bir azalış olduğu gözlenmiştir.

D-17 tuğlalarının basınç dayanımı değeri olarak 45 . günün sonundaki değerleri D-1 tuğlalarının basınç dayanım değerlerinden yüksek olmasının yanı sıra porozitelerinin D-1 tuğlalarına göre daha yüksek olduğu gözlenmiştir. D-15, D-16 ve D-17 tuğlalarına basınç mukavemetini arttırıcı ve poroziteyi düşürücü Melment f10 isimli kimyasal madde katılması ile iyileştirilmesi amaçlanmıştır. Melment f 10 kimyasalı sırasıyla D-15, D-16 ve D-17 tuğlaları için hazırlanan karışımlara ilave edilmiştir. Melment f10 kimyasalının ilave miktarları ise her örnek için 0.5/1000 g, 0.8/1000 g ve 1/1000 g gibi çok küçük miktarlardır. Melment f10 kimyasalının ilavesinin yüksek dayanımlı tuğlalara uygulanmasında, elde edilen en yüksek dayanımı daha iyi hale getirebilmek ve poroziteyi düşürebilmek amaçlanmıştır. Kimyasalın ilave oranlarındaki değişim ise ek ilave kimyasal miktarıyla deney sonuçlarında olabilecek değişimini görebilmek içindir. Melment f10 kimyasalı ilave edilmiş tuğlaların 15. gün sonunda basınç dayanımı ve porozite deneyi sonuçları Tablo 6'da görülmektedir.

Tablo 6'da görüldüğü üzere Melment f10 ilavesi ile tuğlaların basınç dayanımlarını arttırmasının yanı sıra porozitelerininde aynı oranlarda düştüğü gözlenmiştir. Aynı karışım oranlarında olan tuğlalara değişen miktarlarda Melment f10 kimyasalı ilavesinin tuğlalar üzerindeki olumlu sonuçları da Tablo 6'de açıkça görülmektedir.

Tablo 6. D-15, D-16 ve D-17 tuğlalarına farklı oranlarda Melment f10 ilavesiyle elde edilen basınç dayanımı ve porozite değerleri

\begin{tabular}{lrr}
\hline Kod & $\begin{array}{r}\text { Basıç dayanımı } \\
\left(\mathrm{kg} / \mathrm{cm}^{2}\right)\end{array}$ & $\begin{array}{r}\text { Porozite } \\
(\%)\end{array}$ \\
\hline D-15 + 0.5/1000 g Melment f10 & 84.8 & 25.9 \\
D-15 + 0.8/1000 g Melment f10 & 96.5 & 23.8 \\
D-15 + 1/1000 g Melment f10 & 109.7 & 18.0 \\
D-16 + 0.5/1000 g Melment f10 & 85.5 & 26.5 \\
D-16 + 0.8/1000 g Melment f10 & 97.3 & 24.3 \\
D-16 + 1/1000 g Melment f10 & 110.5 & 18.7 \\
D-17 + 0.5/1000 g Melment f10 & 86.0 & 27.0 \\
D-17 + 0.8/1000 g Melment f10 & 97.9 & 24.8 \\
D-17 + 1/1000 g Melment f10 & 113.8 & 19.1 \\
\hline
\end{tabular}


D-15, D-16 ve D-17 tuğlalarına değişik oranlarda Melment f10 katılarak elde edilen tuğla numunelerinin basınç dayanımlarında ve porozitelerindeki reaktif miktarının artışıyla gözlenen değişim sonuçları Şekil 11 ve Şekil 12'de görülmektedir. Tuğlaların basınç dayanımlarını yükselmesi ve porozite değerlerini düşürmesi avantajlarına karşın Melment f10 kimyasalı oldukça pahalı olup \%1 oranındaki Melment f10 ilavesi tuğla maliyetlerini günümüz koşullarında \%25 civarında arttıracağı hesaplanmaktadır.

Basınç dayanımı ve su emme deneyleri sonuçları diğer örnek tuğlalara göre olumlu sonuçlar veren D-15, D16 ve D-17 tuğla numunelerinin Tablo 6'da özetlendiği gibi Melment f10 ilavesinden sonra basınç dayanımlarında yükselme porozitelerinde ise azalma olmuştur. Yani numunelerin poroiteleri azaldıkça dayanımların arttığı görülmektedir. Bu sonuçlarla alçı bazlı tuğlaların porozitelerinin kil tuğlaların porozitelerine göre yüksek olduğu gözlenmiştir. Halen inşaat yapımında kullanılan kil bazlı tuğlaların poroziteleri maksimum \%7 iken Basınç dayanımı en yüksek değerde elde edilen D-17 tuğlalarının porozitesi \%19.1'dir. Bu amaçla D-15, D-16 ve D-17 tuğlalarının porozitelerini düşürmek amacıyla, inşaat sektöründe "Harçta Su Geçirimsizlik Katkısı" olarak kullanılan ve çimento harcının yapımında suya maksimum 1/9 oranında katılan, SICA (Pero Hidro1) isimli kimyasal madde katılarak hazırlanmıştır.

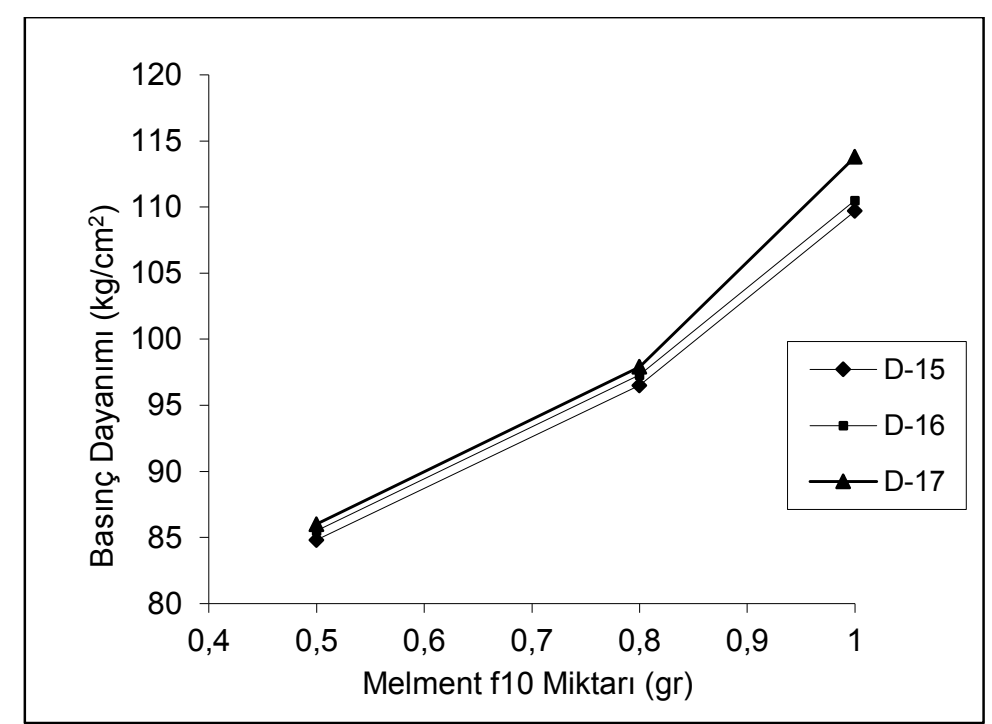

Şekil 11. Melment f10 ilavesiyle tuğlaların basınç dayanımlarındaki değişim

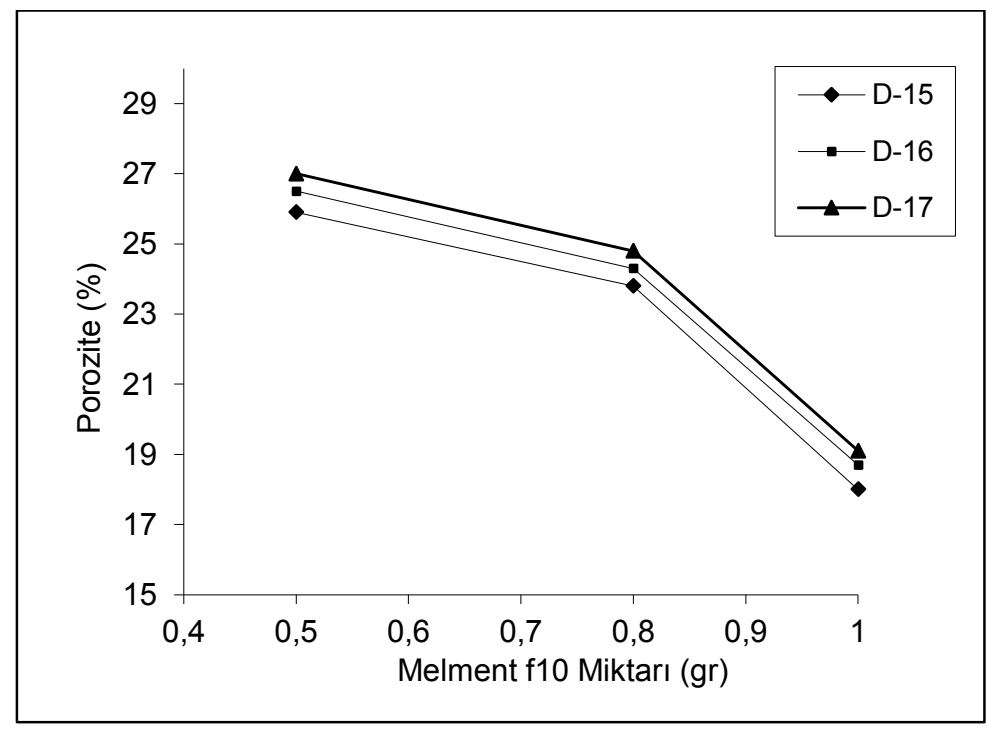

Şekil 12. Melment f10 ilavesiyle tuğlaların porozitelerindeki değişim 
Tuğlaların bu şekilde hazırlanmasından sonra kalıplardan çıkarılan tuğla numunelerinin kuruması beklenilmiş ve tuğlaların yüzeyleri SICA malzemesi ile kaplanmıştır. $\mathrm{Bu}$ şekilde hazırlanan tuğlaların 15 gün sonundaki basınç dayanımları ve porozite deneyi sonuçları Tablo 7'de görüldüğü gibidir.

$\mathrm{Bu}$ sonuçlarla SICA malzemesinin tuğlaların basınç dayanımında herhangi bir değişikliğe yol açmadığı ve dayanımın SICA katılmadan hazırlanan tuğla numuneleriyle aynı olduğu görülmüştür. D-15, D-16 ve D-17 tuğlalarının hazırlanmasında hem su ile $\% 25$ oranında karıştırılarak hem de tuğla yüzeylerine sır olarak kaplanarak kullanılan Sica malzemesi tuğlaların porozitelerini kil tuğlalarda istenilen porozite oranına ( maksimum \%7) düşürdüğü gözlenmiştir.

$15,30,45$ ve 60 'ar gün aralıklarla basınç dayanım ve poroziteleri değerleri Tablo 5 'de verilen tuğla numunelerinin yoğunluk, eğilme mukavemeti ve yüzey sertliği deney sonuçları Tablo 8'de özetlenmiştir.

Tablo 7. SICA ile hazırlanan ve kaplanan D-15, D-16 ve D-17 tuğlalarının porozite ve basınç dayanımı değerleri

\begin{tabular}{lrr}
\hline Kod & Basıç Dayanımı $\left(\mathrm{kg} / \mathrm{cm}^{2}\right)$ & Porozite $(\%)$ \\
\hline D-15 & 83.0 & 5.9 \\
D-16 & 83.7 & 6.3 \\
D-17 & 84.0 & 6.9 \\
\hline
\end{tabular}

Tablo 8. Bekletilen tuğla numunelerinin yoğunluk-eğilme mukavemeti ve yüzey sertliği deney sonuçları

\begin{tabular}{|c|c|c|c|c|c|c|c|c|c|c|c|c|}
\hline \multirow[t]{3}{*}{$\begin{array}{l}\text { Tuğla } \\
\text { no }\end{array}$} & \multicolumn{4}{|c|}{$\begin{array}{l}\text { Yoğunluk }\left(\mathrm{g} / \mathrm{cm}^{3}\right) \\
\text { Bekletilme süreleri }\end{array}$} & \multicolumn{4}{|c|}{$\begin{array}{c}\text { Eğilme mukavemeti }\left(\mathrm{kg} / \mathrm{cm}^{2}\right) \\
\text { Bekletilme süreleri }\end{array}$} & \multicolumn{4}{|c|}{$\begin{array}{l}\text { Yüzey sertliği SHORE D } \\
\text { Bekletilme süreleri }\end{array}$} \\
\hline & 15 & 30 & 45 & 60 & 15 & 30 & 45 & 60 & 15 & 30 & 45 & 60 \\
\hline & Gün & Gün & Gün & Gün & Gün & Gün & Gün & Gün & Gün & Gün & Gün & Gün \\
\hline D-1 & 1,14 & 1,13 & 1,13 & 1,13 & 79,90 & 79,90 & 79,90 & 79,89 & 65 & 65 & 65 & 65 \\
\hline D-2 & 1,02 & 1,01 & 1,01 & 1,01 & 54,70 & 54,90 & 57,40 & 57,40 & 58 & 60 & 60 & 60 \\
\hline D-3 & 0,90 & 0,89 & 0,89 & 0,89 & 25,80 & 26,70 & 29,10 & 29,10 & 41 & 46 & 46 & 46 \\
\hline D-4 & 0,84 & 0,83 & 0,83 & 0,83 & 8,30 & 8,80 & 9,30 & 9,30 & 23 & 28 & 29 & 29 \\
\hline D-5 & - & - & - & - & - & - & - & - & - & - & - & - \\
\hline D-6 & 0,83 & 0,82 & 0,82 & 0,82 & 16,00 & 17,70 & 19,30 & 19,30 & 41 & 45 & 46 & 46 \\
\hline D-7 & 0,82 & 0,81 & 0,81 & 0,81 & 16,60 & 16,80 & 17,40 & 17,40 & 42 & 46 & 46 & 47 \\
\hline D-8 & 0,81 & 0,79 & 0,79 & 0,79 & 18,30 & 19,20 & 20,90 & 20,90 & 43 & 47 & 47 & 48 \\
\hline D-9 & 0,86 & 0,85 & 0,85 & 0,85 & 26,90 & 28,40 & 30,60 & 30,60 & 46 & 49 & 49 & 49 \\
\hline D-10 & 0,85 & 0,84 & 0,84 & 0,84 & 27,40 & 28,90 & 31,10 & 31,10 & 47 & 50 & 51 & 51 \\
\hline D-11 & 0,84 & 0,83 & 0,83 & 0,83 & 27,90 & 29,10 & 31,90 & 32,00 & 48 & 51 & 52 & 52 \\
\hline D-12 & 0,88 & 0,87 & 0,87 & 0,87 & 32,00 & 33,10 & 34,70 & 34,60 & 50 & 53 & 54 & 54 \\
\hline D-13 & 0,87 & 0,86 & 0,86 & 0,86 & 33,50 & 34,80 & 35,60 & 35,60 & 52 & 55 & 56 & 56 \\
\hline D-14 & 0,86 & 0,85 & 0,85 & 0,85 & 35,10 & 36,70 & 37,80 & 37,70 & 53 & 56 & 57 & 57 \\
\hline D-15 & 1,01 & 0,99 & 0,99 & 0,99 & 43,40 & 44,00 & 46,40 & 46,30 & 58 & 61 & 62 & 62 \\
\hline D-16 & 1,00 & 0,98 & 0,98 & 0,98 & 45,00 & 46,80 & 48,80 & 48,80 & 59 & 62 & 63 & 63 \\
\hline D-17 & 0,97 & 0,96 & 0,96 & 0,96 & 47,00 & 48,10 & 51,60 & 51,50 & 62 & 66 & 67 & 67 \\
\hline
\end{tabular}

Tablo 8'de görüldüğü gibi farklı oranlarda sade alçı içeren örnekler birbirleriyle karşılaştırıldığında Sade alçı oranının artmasıyla birlikte yoğunlukların arttı̆̆ gözlenmektedir. Bu durum Tablo 5'de görülen basınç dayanımı sonuçlarıyla karşılaştırıldığında basınç dayanımı ile yoğunluk arasında doğru orantı görülmektedir. Diğer yandan porozite ile yoğunluk arasında ters orantı olduğu gözlenmiştir. Yoğunluk arttıkça tuğlaların porozitelerinin azaldığ görülmektedir. Bununla birlikte karışım oranları dikkate alınmaksızın yüksek oranlarda poroziteye sahip numunelerin düşük dayanımlara sahip oldukları gözlenmiştir. Eğilme mukavemeti değerlerinin basınç dayanımıyla doğru orantıda arttıkları görülmektedir. Eğilme mukavemeti değerlerinin de basınç mukavemeti değerlerinde olduğu gibi bekleme süreleri ile 45. güne kadar arttığı daha sonra ise sabit kaldığ1 görülmektedir. Tuğlaların yüzey sertliklerinin de alçı oranlarıyla dolayısıyla basınç dayanımlarıyla birlikte artış gösterdiği gözlenmektedir. Yüksek basınç dayanımı gösteren tuğlaların yüzey sertliklerinin de aynı oranda arttığı görülmektedir.

Tablo 8'de \%70 sade alçı oranlarıyla imal edilen 
tuğlalar incelendiğinde yüzey sertliği ve eğilme mukavemeti en yüksek tuğlaların D-17 tuğlaları olduğu görülmektedir. Yoğunluğu yüksek olan tuğla ise D-15'tir. Tablo 5 ve Tablo 8 birlikte incelendiğinde genel olarak tuğlaların artan alçı oranlarıyla basınç dayanımlarının, yoğunluklarının, eğilme mukavemetlerin ve yüzey sertliklerinin arttığı, porozitelerin ise düştüğü gözlenmektedir. Uçucu külün aynı alçı oranlarındaki tuğlalarda, arttıkça dayanımı düşürüp su emmeyi arttırdığı ama kireçle kıyaslandığında ise uçucu külün daha az porozite artışına sebep olduğu görülmektedir.

Karışım oranları dikkate alınmaksızın Tablo 8'de görüldüğü gibi D-1 tuğlalarının yoğunlukları diğer tuğlalara göre daha yüksektir. $\mathrm{Bu}$ tuğlaların yoğunluğunun yüksek olması şüphesiz ki sade alçının özgül ağırlığının uçucu kül ve kirece oranla daha yüksek olmasıyla ilişkilidir. Diğer yandan D-1 tuğlalarının basınç dayanımları ve yüzey sertlikleri D17 tuğlalarına göre bekleme süreleri dikkate alındığında daha düşüktür. Yoğunluğu düşük, basınç dayanımı ve yüzey sertliği yüksek olan D-17 tuğlaları diğer örneklere göre daha avantajlı olduğu görülmektedir.

Tablo 8'deki 60 günlük bekleme verileri kullanılarak numunelerin yoğunluk, eğilme mukavemeti ve sertlik değerleri arasındaki ilişkiler belirlenmiştir. Buna göre; yoğunluk ile eğilme mukavemeti arasında yüksek korelasyonlu doğrusal bir ilişki (Şekil 13), yine Shore sertliği ile eğilme mukavemeti arasında yüksek korelasyonlu üssel bir ilişkinin olduğu ortaya konmuştur (Şekil 14).

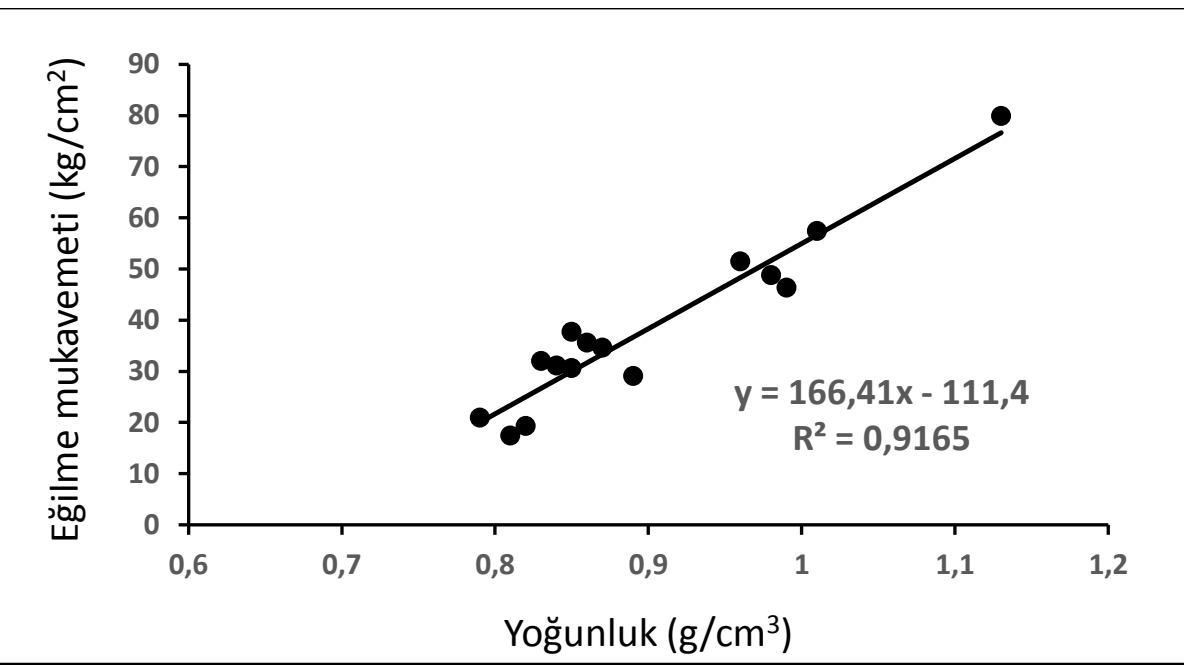

Şekil 13. Tüm numunelerin yoğunluk ile eğilme mukavemeti arasındaki ilişkisi

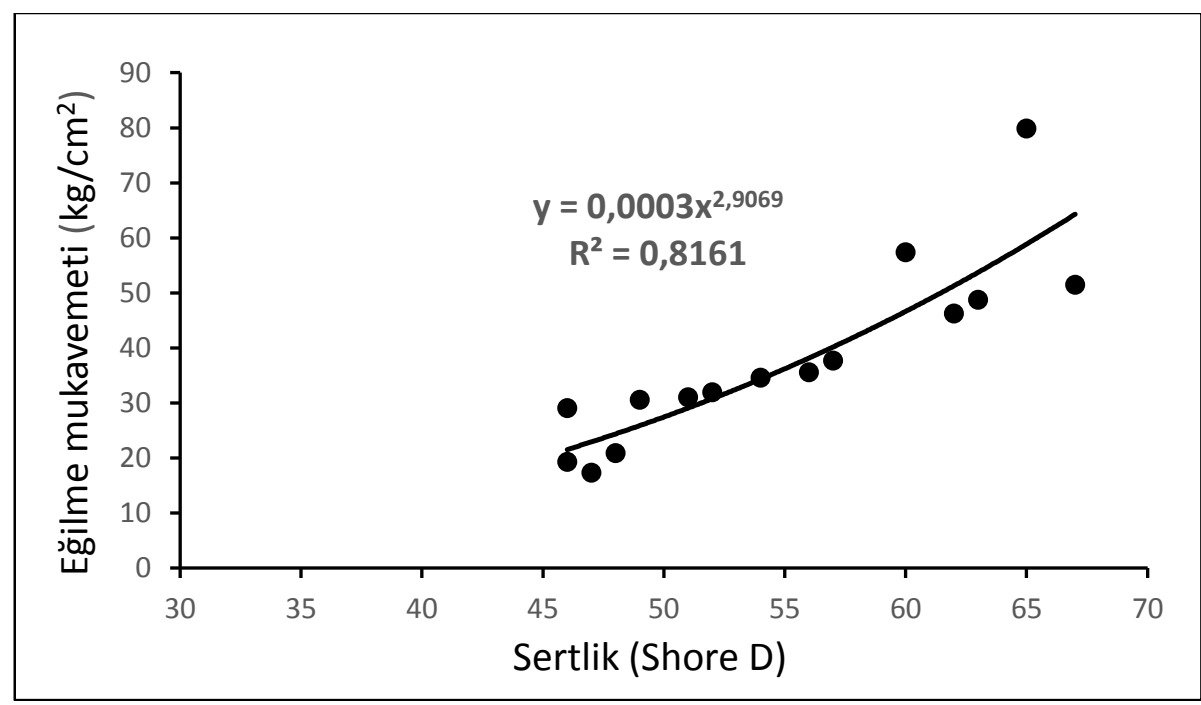

Şekil 14. Tüm numunelerin sertlik ile eğilme mukavemeti arasındaki ilişkisi 


\section{Sonuçlar}

Laboratuvarda üretilen tuğlalar sade alçı, uçucu kül ve kireç üzerine su ilavesi ile tepkimeye giren çimento harcı kıvamında kalıplara boşaltılarak elde edilen bir malzemedir. Betona benzer şekilde, üretilen tuğlaların basınç dayanımları ve eğilme mukavemetleri bekleme süreleriyle artmakta ve 45 . gün sonunda yapılan deneylere kadar bu artış devam etmektedir. Daha sonra bu artışların durduğu ve sabitlendiği görülmektedir.

En yüksek basınç dayanımına sahip D-17 tuğlalarının su emmeleri diğer karışım oranları ile üretilen tuğlaların su emmelerine oranla daha düşük olmasının yanında D-1 olarak isimlendirilen \%100 sade alçıyla üretilen tuğlalara oranla su emmeleri yüksektir. Bu dezavantaj D-17 tuğlalarının karışımına 1/1000 g Melment f10 ilavesi ile giderilmiş ve D-17 tuğlalarının su emmeleri \%45.8'den \%19.1'e indirilmiştir. Ayrıca Melment f10 ilavesi bu tuğlaların basınç dayanımları da $92.8 \mathrm{~kg} / \mathrm{cm}^{2}$ 'den $113.8 \mathrm{~kg} / \mathrm{cm}^{2}$ 'ye yükselmiştir.

Alçı, kireç ve uçucu küle göre daha belirgin bağlayıcı özelliğe sahiptir. Buda tuğlaların artan alçı oranlarıyla basınç dayanımlarının, eğilme mukavemetlerinin, yüzey sertliklerinin, yoğunluklarının artmasına ve su emmelerinin azalmasına neden olmaktadır. Artan uçucu kül oranları tuğlalarının basınç dayanımlarının azalmasına ve su emmelerinin artmasina neden olmaktadır. Sade alçı, uçucu kül ve kireç malzemeleriyle üretilen tuğlaların uçucu kül ve kireç içeriği arttıkça su emmeleri artmış, yoğunlukları arttıkça ise su emmeleri azalmıştır.

Üretilen tuğlalarda en yüksek basınç dayanıma ve en düşük su emmeye sahip D-17 numunelerinin yoğunlukları $0.96 \mathrm{~g} / \mathrm{cm}^{3}$ olarak hesaplanmıştır. Kil bazlı tuğlaların ise Türk standartlarında belirtilen yoğunlukları 1.4-2.2 g/ $\mathrm{cm}^{3}$ arasındadır.

Üretilen tuğlalarla kil tuğlalar kıyaslandığında alçı bazlı tuğlalar bina yapımında kullanıldığında binalardaki ölü ağırlığı azaltacak ve işçilik maliyetleri başta olmak üzere inşaat maliyetlerini de düşürecektir.

İnşaat sektöründe kullanılan kil bazlı tuğlalardan fabrika tuğlalarının basınç dayanımları ortalama 25-75 $\mathrm{kg} / \mathrm{cm}^{2}$ iken D-17 tuğlalarının basınç dayanımı 92.8 $\mathrm{kg} / \mathrm{cm}^{2}$ olarak elde edilmiştir. Melment f10 ilavesiyle D-17 tuğlalarının basınç dayanımları $113.8 \mathrm{~kg} / \mathrm{cm}^{26}$ ye kadar yükselmiştir.

$\mathrm{Bu}$ sonuçlara göre $\mathrm{D}-17$ tuğlalarının gerek yoğunluğunun düşük olması gerekse basınç dayanımlarının yüksek olması bina yapımında kullanılan kil bazlı tuğlaların yerine D-17 tuğlasının kullanılabileceği sonucuna varılmıştır.

Alçı bazlı tuğlaların dezavantajları ise, D-17 tuğlalarının $\quad \mathrm{su}$ emmelerinin minimum $\% 19.1$ oranlarına kadar düşürülmesidir. Piyasada kullanılan kil bazlı tuğlaların su emmeleri maksimum \%7'dir. Bu durumda görüldüğg̈ gibi alçı bazlı tuğlaların su emmeleri kil bazlı tuğlalara göre daha yüksektir. Alçı bazlı tuğlaların su emmelerini kil tuğlaların su emmelerine yakın hale getirebilmek için inşaat sektöründe kullanılan Sica ticari isimli harçta su geçirimsizlik katkısı kullanılmıştır. Sica malzemesi D15 , D-16 ve D-17 tuğlalarının hem harç hamurlarının hazırlanmasında suyun \%25'i olarak hem de kalıptan çıkarıldıktan sonra yüzeylerine sır olarak kaplanması şeklinde uygulanmıştır. Bu şekilde hazırlanan D-15, D-16 ve D-17 tuğlalarının su emmeleri sırayla \%5.9, $\% 6.3$ ve \%6.9 olarak bulunmuştur.

Bu sonuçlardan sonra hazırlanan uçucu kül katkılı alçı tuğlaların halen inşaat sektöründe kullanılan kil tuğlalara alternatif olarak üretilebileceği ve uçucu külün optimum \%10-15 oranında kullanılabileceği ortaya konmuştur. Alçı, uçucu kül ve kireç rezervleri bakımından çok zengin olan Sivas bölgesinde endüstriyel ölçekte hafif tuğla üretimi için $\mathrm{ArGe}$ çalışmalarına hız verilmelidir.

\section{Teşekkür}

Yazarlar bazı deneylerin yapılmasinda laboratuvar imkanlarını sağladıkları için Sivas BMT A.Ş.'ne teşekkür ederler.

\section{Kaynaklar}

[1] Türker P. Erdoğan B. Katnaş F. Yeğinobalı A. 2009 Türkiye'deki uçucu küllerin sinıflandırılması ve özellikleri, TÇMB / AR-GE / Y03.03, Ankara, $112 \mathrm{s.}$ [2] Özmen, E., Termik Santral Küllerinin Yönetimi, 2011 Atık Yönetimi Sempozyumu Programı, 16-21 Nisan 2011,Sueno Hotel Beach-Side / ANTALYA [3] Kızgut S. Çuhadaroğlu D. Çolak K., 2001, Çatalağzı termik santrali uçucu küllerinden tuğla üretim olanaklarının araştırılması, Türkiye 17. Uluslararas1 Madencilik Kongresi ve SergisiTUMAKS 2001, (c) ISBN 975-395-416-6.

[4] Bentli İ. Uyanık A.O. Demir U. Şahbaz O. Çelik M.S.,2001, Seyitömer termik santrali uçucu küllerinin tuğla katkı hammaddesi olarak kullanımı, Türkiye 17. Uluslararas1 Madencilik Kongresi ve SergisiTUMAKS 2001, (c) 2001, ISBN 975-395-416-6.

[5] Kumar S. 2002, A perspective study fly ash-limegypsum bricks and hollow blocks for low cost housing development, Department of Civil Engineering, 
Harcourt Butter Technological Institute, Kanpur 208002, India.

[6] Atiş C.D. Gorur E.B. Karahan O. Bilim C. İlkentapar S. Luga E. 2015, Very high strength (120 $\mathrm{MPa})$ class $\mathrm{F}$ fly ash geopolymer mortar activated at different $\mathrm{NaOH}$ amount, heat curing temperature and heat curing duration, Construction And Building Materials, vol.96, pp.673-678.

[7] Naganathan S. Mohamed A.Y.O. Mustapha K.N. 2015, Performance of bricks made using fly ash and bottom ash, Construction and Building Materials, Volume 96, Pages 576-580.

[8] Consoli N.C. Rocha C.G. Saldanha R.B. 2014, Coal fly ash-carbide lime bricks: An environment friendly building product, Construction and Building Materials 69 Pages 301-309.
[9] Cultrone G. Sebastián E. 2009, Fly ash addition in clayey materials to improve the quality of solid bricks, Construction and Building Materials 23 Pages 11781184.

[10] Şengül Ü. 2002, Kangal termik santralinde uçucu kül atımının çevresel etkileri, ÇEVKOR, Cilt11 Sayı 44, 21-24s.

[11] Şengül, Ü. ve Güler, R., 2001, Kangal Termik Santrali Küllerinin Çimento Katkı Maddesi Olarak Kullanılabilirliği, C.Ü. Fen Edebiyat Fak. Fen Bilimleri Dergisi 22-1/2001, Sivas. 